\title{
Entrepreneurship Concepts: The perceptions of Malay businesses on Malaysia - Thailand Cross-Border
}

\author{
Muhammad Abi Sofian Abdul Halim, Khatijah Omar, Hazman Samsudin
}

\begin{abstract}
Previous studies have found that smuggling is the economic activity of Malay traders on the borders of Malaysia Thailand which is easy, cheap, fast, and does not need to comply with complex regulations. Rantau Panjang town, Pengkalan Kubor, Tak Bai and Narathiwat are among the locations of two countries that involved in smuggling among entrepreneurs, wholesalers, and retailers. This problem has been a major issue for the Enforcement and Legislation Unit, the Royal Customs and Excise Department, the Immigration Department and the Royal Malaysian Police in managing the controls and actions along this border. Hence, the objective of this study is to review the perception of Malay traders in Rantau Panjang and Pengkalan Kubor on the importance of entrepreneurial concepts as a healthy practice in their business. Using AIDA Model, this study covers Malay traders in Rantau Panjang and Pengkalan Kubor as respondents. This study conducted a structured interview to measure the respondents' perception in terms of their way of thinking, attitude and entrepreneurial culture. The findings of this study showed that their entrepreneurial perspective focuses on the level of observation and interest, and they are less likely to improve their entrepreneurial desire as an entrepreneur. In fact, this finding also shows that entrepreneurial thinking, attitudes and culture are decreasing. This shows that most Malay traders on the Malaysia - Thailand border are small traders that still have to deal with market competition and unsystematic business chains, causing them to be bounded with smuggling activities in their businesses. In conclusion, this study shows that there are still many Malay traders on the border that lack of understanding of entrepreneurial concepts in their business as discussed earlier by entrepreneurial thinkers and researchers.
\end{abstract}

Keywords : Borders, Entrepreneurship Entrepreneurial Attitude, Entrepreneurial Thinking, Malay Traders, Smuggling Economy

\section{INTRODUCTION}

Today, the bustling economic activity on the Malaysia-Thailand border has produced many Malay traders who run their businesses along the Golok River. This economic activity has long been operated between the Malay community in Rantau Panjang and Pengkalan Kubor, Kelantan with the Malay community in Narathiwat, Thailand. Even the Malay community of southern Thailand thinks that the Malay clan in southern Thailand is the same as the Malay clan in Malaysia, Indonesia, Singapore and Brunei and what distinguishes them from each other is only the politics practiced by Thailand which is the Buddhist-based politics [1]. Despite the fact that business activities between these two nations have been placed, many of Malay traders are doing business through smuggling of goods from Thailand. Indeed, the biggest issue that is faced by the local traders is the problem of cross-border crime, which is smuggling, that makes it difficult for better and healthier economic development at the border.

As previously known, good entrepreneurial concepts are the concepts that guide those who conduct business ethically and abide the rules set out in order to spur the economic activities of a country [2]. A good entrepreneurial criterion will adhere to the entrepreneurial personality factor such as the desire to succeed [3], dare to take risk [4], possess high self-confidence [5], have good internal self-control [6] and be motivated to develop business goals [7]. Hence, the definition of entrepreneurial concept must meet all the criteria previously discussed by the researchers.

\section{BACKGROUND OF THE STUDY}

The $29.9 \mathrm{~km}$ Golok River is a border separating Thailand and Malaysia. The Malaysia - Thailand border involves several small towns in the northern part of Malaysia, such as Tumpat (Pengkalan Kubor), and Rantau Panjang in Kelantan. Apart from that, two towns on the west coast of Peninsular Malaysia abutting this border which are Bukit Kayu Hitam in Kedah and Padang Besar in Perlis. In southern Thailand, there are four provinces which abut the border which are Narathiwat, Yala, Songkhla and Satun. Political differences between these two countries do not rule out the friendship among the border communities. Instead, the long-standing affiliation in this border community that has different government does not prevent them from strengthening their 
relationship and running their business well under one economic group.

Interestingly, various news has been heard about the conflict that struck eastern communities on the Malaysia Thailand border, but the economic activity of micro, small and medium businesses around it is still growing well. In fact, southern Thailand's economic development has also had a positive impact on small and medium-sized entrepreneurs in northern Kelantan, Kedah and Perlis, the northern Malay states which are close to the border. Although the authorities of both countries work very hard to eradicate the smuggling activities and business networks that violate the law, smuggling keeps on occurring. According to Fauzi Hussin, Norehan Abdullah, Hussin Abdullah and Selamah Maamor [8], there are some views agreeing that without smuggling activities at Sungai Golok boundary and Rantau Panjang area, the economic activity of the area will be paralyzed and community's income will be affected as it is the main source of revenue for some of the communities along the border. Habibah Ahmad, Hamzah Jusoh, Er Ah Choy, Amriah Buang, Sivapalan Selvadurai, Nurfarahin zainuddin, Mohd Kamarulnizam and Sri Winarni Samsir [9] also agreed with this opinion and added that the diversity of local products on the border has attracted foreign tourists to visit and shop in small-scale premises and encourage informal tourism services.

However, if this activity is left untouched, it will create a national security issue where the entry of illegal goods such as weapons and drugs is difficult to contain. In fact, human trafficking activities are relatively active throughout the border and the governments of both countries have also suffered from huge economic losses such as the flow of Malaysia's petrol subsidies to Thailand and the failure to collect international trade tariffs which is also source of income to both countries. For example, according to Bernama's newspaper dated August 3, 2017, Thai local authorities have been able to overthrow drug trafficking to Malaysia worth RM100 million. According to the International Labor Organization (ILO) it is estimated that the size of the human trafficking economy is estimated to be RM48 billion per year and if 5\% of this amount comes from the Malaysia-Thailand border, it is equivalent to RM2.4 billion a year. This has not yet been taken into account in terms of the failure to collect tariffs and outflow subsidies that are estimated to be hundreds of millions ringgit. This shows that, the size of the economic trafficking in Malaysia Thailand is huge and should be tackled seriously. The possible positive and negative impacts of the smuggling activities are imbalance, when the negative impacts outdo the positives ones.

To curb this situation, the law needs to be tightened and enforced. Law without enforcement is meaningless. However, it is understood that the staff shortage factor and the less efficient monitoring system to combat this activity make enforcement is not an easy matter. Therefore, in order to control this activity, it is necessary to start with nurturing the awareness towards ethical business practice among communities living alongside these boundaries. In this regard, the level of entrepreneurship awareness and ethical actions in daily business need to be examined in order to assess the seriousness of the problems with regards to business activities along Malaysia-Thailand border.

\section{CONCEPT OF ENTREPRENEURSHIP IN MALAYSIA - THAILAND}

Knowing the fact that these smuggling activities help micro, small and medium entrepreneurs in southern Thailand as well as in northern Malaysia, the Malaysian government through several agencies involved has tried to cooperate with the Thailand government to find solutions to this conflict as well as to bring improvements toward community development from economic, political, security and social aspects [10]. The cooperation among the Malay communities in Patani, Yala and Narathiwat with communities in Pengkalan Kubor, Rantau Panjang, Bukit Kayu Hitam and Padang Besar should be nurtured to rebuild the integrity of identity, culture, language and religion through business activities even though at the same time, conflicts occur among communities along this border. According to Anand Penyarahun, the former Prime Minister of Thailand who is also the chairman of the National Peace Commission (SPN) stated that the purpose of the SPN is to help in resolving the political conflict that is taking place in southern Thailand and its impact on social, economic and identity development [1]. In fact, the Malaysian government has channeled various assistance and training that could help Malay traders along the Malaysia - Thailand Border to be able to do business according to the rules set. This is in line with what has been stated by McClelland [3] who stated that the personality of a good entrepreneur is essential to conduct business in compliance with rules and ethics.

\section{Figure 1: Malay Malaysia- Thailand entrepreneurial cultural} relations border

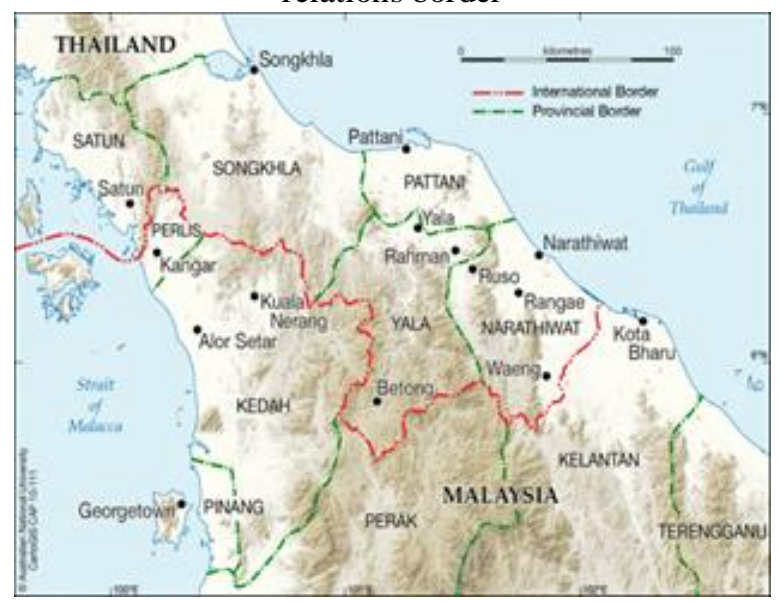

Source: http://asiapacific.anu.edu.au

\section{PROBLEM STATEMENT}

Insurgency and political unrest issues in Patani, has started since 2004 and has a major impact on all communities in southern Thailand includes Yala, Narathiwat and Patani. This problem has also had a devastating effect on social and economic activities among communities across the Malaysia - Thailand border. According to Che Mohd Aziz Yaacob [1], the history of the 
Siamese conflict has begun since 1786 when the Patani Malay Sultanate government was defeated and conquered by the Siamese government. Hence, the Malays along the borders of Malaysia - Thailand today face various socio-cultural and economic problems that affect their well-being and quality of life. In fact, the Thai government administration focuses more on the development in northern Thailand and has caused the Malay community in southern Thailand to be neglected and lacking in attention. All of these have brought negative impacts on the Malays in the Malaysia - Thailand border, such as smuggling, mafia and human trafficking. According to Che Mohd Aziz Yaacob [1], there are about 130 illegal business spots along the Golok river which involve smuggling and trafficking activities as the main source of livelihood for the Malay community here and many of these small businesses hope that the authorities would not take serious action against them who are just doing business on small scale.

According to Fauzi Hussin et al. [8], most business items brought in and out the border are through smuggling and are illegal. There has been much effort to prevent illegal activities by the Enforcement and Legal Unit (UPP), Royal Malaysia Customs Department, the Immigration Department and Royal Malaysia Police Department (PDRM) and to restrict the smuggling activities of artificial clothing, rice, sugar and household appliances, but the problem remains unsolved. According to Che Mohd Aziz Yaacob [1], about 130 bases or spots along the Golok river from Pengkalan Kubor, Tumpat to Rantau Panjang are still active in smuggling activities. Table 1 below shows the number of smuggled products from Thailand to Malaysia and from Malaysia to Thailand.

Table 1: List of smuggled Malaysian-Thai products

\begin{tabular}{|l|l|}
\hline \multicolumn{1}{|c|}{$\begin{array}{c}\text { Smuggling from } \\
\text { Thailand to Malaysia }\end{array}$} & \multicolumn{1}{c|}{$\begin{array}{c}\text { Smuggling from } \\
\text { Malaysia to Thailand }\end{array}$} \\
\hline i. Rice & i. Sugar \\
\hline ii. Artificial Clothes & ii. Wheat \\
\hline iii. Fruits & iii. Cooking Oil \\
\hline iv. Vegetables & iv. Kitchen Needs \\
\hline v. Kitchen Utensils & vi. Petrol \\
\hline vii. Firework & \\
\hline
\end{tabular}

\section{LITERATURE REVIEW}

Some past research has been reviewed to further strengthen this study from theoretical and imperative aspects. Many previous findings were found to have potential to assist and support the objectives of this study. According to some entrepreneurial experts such as McClelland [3], Casson [4], Gurol and Atsan [5], Shane et al. [6] and Hansemark [7], they suggested that a businessman is different from an entrepreneur, whereby an entrepreneur must have a good personality such as dare to take risk, have self-confidence, self-control and have high motivation to develop and achieve business goals. Hans De Marie and Isidore Collins [2] also added that following rules and ethics in business would create a better business environment. However, Bruns, Miggelbrink and Muller [11] found that international economic activities across borders have been accepted by the surrounding communities in post socialist countries even though they are against the law. Merriman, Joossens, Frank and Yurekli [12] added that regulatory and enforcement along the border are not transparent, especially in terms of payment of goods taxes. Meanwhile, Dutta [13] supported both previously stated opinions and stated that co-operation and understanding are crucial in the effort to internationalize small businesses as well as to increase economic growth across the borders of Bangladesh.

Because of loose control and enforcement, mafia, smuggling and terrorism often take place along Malaysia-Thailand border [10]. The occurrence of religious conflicts in Tak Bai and Kerisek in 2004 has threatened the security of the Malay community and Malay entrepreneurs on the Malaysia - Thailand border. However, the effort to mitigate this dispute involving the local authorities and minority ethnics in southern Thailand has been assisted by various organizations and other government agencies such as ASEAN, UN and OIC. Both Malaysia and Thailand have taken some action to solve the issue. The Thai government has tried to solve the problem of social conflicts on the Thai border through restructuring of community administrations, such as the National Reconciliation Commission (NRC), the re-establishment of Southern Border Provinces Administrative (SBPAC) and cooperate with Malaysia to jointly settle the issue. In this regard, the issue of smuggling and social conflict that has taken place along the Malaysia Thailand border has also influenced the business management.

\section{OBJECTIVES OF STUDY}

In line with the goals of the Malaysian and Thai governments to solve cultural and economic relations at the border, this research was conducted to explore the socio-cultural development of Malay entrepreneurs along the Malaysia-Thailand border to obtain detailed and significant information. Hence, this research has raised the question of how far the concept of entrepreneurial culture can solve the problem of the economic culture of smuggling among Malaysians along the Malaysia - Thailand border. This question was formed based on previous research discussions, reports by Smuggling Prevention Unit and PDRM, current press and previous observations. In response to stated question, this research was conducted to fulfill the objective of the study focusing on the views of the Malay entrepreneurs in Rantau Panjang and Pengkalan Kubor on the importance of entrepreneurial concepts in their business.

\section{METHODOLOGY}

To achieve the objectives of this study, a qualitative study approach was conducted through interviews with 10 entrepreneurs operating in Rantau Panjang and 9 of them are in Pengkalan Kubor. The interview sessions took 4 days, which was 2 days in Rantau Panjang and another 2 days in Pengkalan Kubor. Table 2 below shows the number of Malay entrepreneurs who were interviewed based on their product sales and location. Since there was a large number of Malay entrepreneurs in Rantau Panjang and Pengkalan Kubor who are not registered with the Companies Commission of Malaysia (SSM), and only help and continue their family business with no permanent address to their premises, this 
leads to a major constraint to the researchers to obtain the accurate number of Malay entrepreneurs who run their own business. In other words, the number of entrepreneur populations in the area can not be identified because they are not legally registered and this too actually is a major problem for any study that investigates illegal activities and black market. All these interviews were recorded and documented before a descriptive study was conducted to measure their perception based on frequency and percentage.

Next, to measure the perception of the Malay entrepreneurs on the importance of entrepreneurial culture development, structured interviews were conducted with respondents. AIDA concept (attention, interest, desire, action) has been applied to develop items for this structured interview. Table 3 below shows the items developed for this structured interview.

Table 3: List of items in structured questionnaires

\begin{tabular}{|l|l|}
\hline 1. Demography \\
\hline 1.1 Age & 1.3 Gender \\
\hline 1.2 Operating Period & 1.4 Product \\
\hline
\end{tabular}

\section{Attention}

\begin{tabular}{|c|l|}
\hline 2.1 & $\begin{array}{l}\text { Have you ever heard the word } \\
\text { entrepreneurship? }\end{array}$ \\
\hline 2.2 & $\begin{array}{l}\text { What is your perception on entrepreneurial } \\
\text { concepts in business? }\end{array}$ \\
\hline 2.3 & $\begin{array}{l}\text { Are that many entrepreneurs in the area } \\
\text { practicing entrepreneurial culture? }\end{array}$ \\
\hline
\end{tabular}

\section{Interest}

\begin{tabular}{|c|l|}
\hline 3.1 & $\begin{array}{l}\text { Are you inclined to deepen your knowledge of } \\
\text { entrepreneurship? }\end{array}$ \\
\hline 3.2 & $\begin{array}{l}\text { What do you think of bringing the local } \\
\text { entrepreneur's interest towards } \\
\text { entrepreneurship? }\end{array}$ \\
\hline 3.3 & $\begin{array}{l}\text { Does the environmental factor affect } \\
\text { entrepreneurship culture? }\end{array}$ \\
\hline
\end{tabular}

\section{Desire}

\begin{tabular}{|l|l|}
\hline 4.1 & $\begin{array}{l}\text { Are you willing to sacrifice your money and } \\
\text { time to explore the knowledge of } \\
\text { entrepreneurship? }\end{array}$ \\
\hline 4.2 & $\begin{array}{l}\text { How to create the local entrepreneur's desire } \\
\text { towards entrepreneurship culture? }\end{array}$ \\
\hline 4.3 & $\begin{array}{l}\text { Do the entrepreneurs here already have the } \\
\text { desire to be more advanced in business? }\end{array}$ \\
\hline
\end{tabular}

\begin{tabular}{|c|l|}
\hline \multicolumn{2}{|c|}{ 5. Action } \\
\hline 5.1 & $\begin{array}{l}\text { Do you respect/comply to your role as an } \\
\text { entrepreneur? }\end{array}$ \\
\hline 5.2 & $\begin{array}{l}\text { What are the actions that have been taken to } \\
\text { become an entrepreneur? }\end{array}$ \\
\hline 5.3 & $\begin{array}{l}\text { Do you agree to introduce the entrepreneurial } \\
\text { concept to the entrepreneurs/ business people } \\
\text { here? }\end{array}$ \\
\hline
\end{tabular}

Overall, this survey has interviewed entrepreneurs whose age is over 20 years; 3 entrepreneurs aged between 20 - 29 years (15.7\%); 5 entrepreneurs between 30 - 39 years (26.2\%); 10 entrepreneurs between $40-49$ (52.4\%); and 1 entrepreneurs over 50 years $(5.7 \%)$. While the gender is dominated by female, 11 entrepreneurs $(58.1 \%)$ and 8 entrepreneurs are male (41.9\%). Meanwhile, based on products, this study interviewed 5 clothing business entrepreneurs (26.2\%); 6 food entrepreneurs (31.4\%); 5 kitchen utensils entrepreneurs (26.2\%); and 3 entrepreneurs who sell home appliances/equipments $(16.2 \%)$. All of these entrepreneurs have been operating their business for more than 5 years; 6 entrepreneurs $(31.4 \%)$ have been operating between 5 - 10 years; 11 entrepreneurs $(58.1 \%)$ between 11 14 years and 2 entrepreneurs $(10.5 \%)$ have been operating for more than 15 years.

Figure 2: The perception of Malay entrepreneurs on the concept of entrepreneurial culture

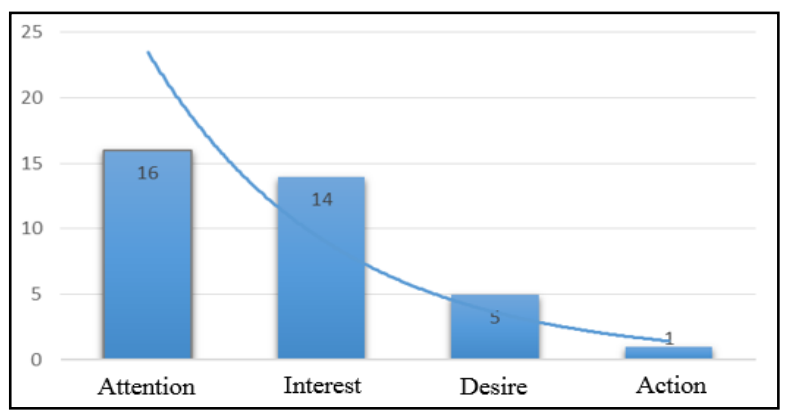

Next, the findings of this study have shown that many of the respondents are highly attentive and interested in this concept of entrepreneurial culture. In fact, they argued that the concept of entrepreneurial culture is among the Islamic approaches required by Allah Almighty. In truth, many of them are impressed with the success story of Rasulullah as a successful entrepreneur through the practices of Islam. However, as explained in Figure 2, they mostly focus on attention and interest of the concept of entrepreneurial culture only and are less likely to increase their desire to be an entrepreneur. In other words, their actions do not reflect their knowledge in the concepts and cultures of real entrepreneurship. In fact, no one has stated that they will adhere to the entrepreneurial culture in their business.

The economic practice of smuggling in their business culture has enabled them to easily operate their daily business. They stated that the concept of entrepreneurship culture is good in business practice but as a human being it is necessary to earn a living. To further explore this descriptive data, a Malay entrepreneur's response in Rantau Panjang is presented below:

"........doh kalu krajaen nok buak tindakan sapa so gok, doh mok cik nok make ape? ...... ..abislah kedai-kedai sini tutup blakelah, tak dok pitislah orang sini ... nyaknye orang sini .... ...pah tu orang dinung pung bukannya orang lain, orang kita gok, sedare-mare belake" 
The findings based on the graphs and the statements from the said respondent have revealed that they do pay serious attention to the concept of entrepreneurial culture. In fact, they are keen to further explore entrepreneurship knowledge if it can facilitate their business activities.

Next, to examine the perception of Malay entrepreneurs on the entrepreneurial concept, the AIDA's measurement looks at three things: entrepreneurial thinking, entrepreneurial attitude and entrepreneurial culture. Table 4 below reveals that the respondents' level of thinking is very high on this entrepreneurial concept whereby all entrepreneurs show their interest in entrepreneurship. Nevertheless, only 12 entrepreneurs are willing to know this concept in depth and only one person who is mindful of his actions in his daily business. While in terms of entrepreneurial attitude, it was found that 16 entrepreneurs are with entrepreneurial attitude and followed by 14 entrepreneurs who are interested, 5 entrepreneurs who are willing and have taken action to be advanced in their business. With regard to the entrepreneurial culture, those entrepreneurs have gone through the life as entrepreneurs, but only the actions that do not really follow or reflect the characteristics of a true entrepreneur.

Table 4: The perception of Malay entrepreneurs on Entrepreneurship

\begin{tabular}{|l|c|c|c|c|}
\hline \multicolumn{1}{|c|}{ Perception } & Attention & Interest & Desire & Action \\
\hline $\begin{array}{l}\text { Entrepreneuri } \\
\text { al Thinking }\end{array}$ & $\begin{array}{c}19 \\
(100 \%)\end{array}$ & $\begin{array}{c}19 \\
(100 \%)\end{array}$ & $\begin{array}{c}12 \\
(63.2 \%)\end{array}$ & $\begin{array}{c}6 \\
(31.6 \%)\end{array}$ \\
\hline $\begin{array}{l}\text { Entrepreneuri } \\
\text { al attitude }\end{array}$ & $\begin{array}{c}16 \\
(84.2 \%)\end{array}$ & $\begin{array}{c}14 \\
(73.7 \%)\end{array}$ & $\begin{array}{c}5 \\
(26.2 \%)\end{array}$ & $\begin{array}{c}5 \\
(26.2 \%)\end{array}$ \\
\hline $\begin{array}{l}\text { Entrepreneurs } \\
\text { hip culture }\end{array}$ & $\begin{array}{c}14 \\
(73.7 \%)\end{array}$ & $\begin{array}{c}16 \\
(84.2 \%)\end{array}$ & $\begin{array}{c}16 \\
(84.2 \%)\end{array}$ & $\begin{array}{c}9 \\
(47.6 \%)\end{array}$ \\
\hline
\end{tabular}

\section{CONCLUSION}

Overall, this study examines the perception of Malay entrepreneurs in Rantau Panjang and Pengkalan Kubor on the importance of entrepreneurial concepts in their business. The perception was examined from the perspective of their thinking, attitude and culture in entrepreneurship. Preliminary findings show that most Malay entrepreneurs on the Malaysia - Thailand border are keen on this entrepreneurial concept, however, the AIDA concept has proven that they are not really willing to practice them in their business. All of this is due to the economic factors which is smuggling in businesses that already fits in the culture of small and medium entrepreneurs. When such activities have become part of the culture and the norms of life, it is difficult to change their actions to not to be involved in this smuggling economy. In other words, once it becomes a habit, it is a problem to change as habits die hard. However, the respondents are willing to become Malay entrepreneurs equipped with the real entrepreneurial concept if their business dealings can easily be managed and provide good returns. In the other perspective, many Malay entrepreneurs along the borders admitted that if they totally adhere to this entrepreneurial concept, they will suffer losses and lose these business opportunities to other groups.

This study also found that the respondents' perception on entrepreneurial thinking, attitudes and culture are very high only towards the element of attention. The respondents are less willing to take action to abandon the smuggling culture in their business. The findings of the study also disagreed with the discussion of previous studies stating that the practice of entrepreneurial concept would be able to eliminate the smuggling culture along the Malaysia Thailand border. In conclusion, the findings show that there are still many Malay traders on the border that lack the understanding of entrepreneurial concepts in their business as discussed by previous entrepreneurial thinkers and researchers. This is to say, the smuggling economy along the Malaysia - Thailand border is very difficult to stave off. As discussed, both governments incur huge revenue losses as a result of outflow subsidies and tariffs that are failed to be collected, high cost of enforcement operations as well as social security issues. Thus, in view of the findings of this study, the governments of both countries are encouraged to invest in education and to raise the awareness of the economic impacts in a bigger picture rather than the local micro economic issues. Authorities should also create new economic opportunities so that local businesses can shift away from smuggling economy.

\section{REFERENCES}

1. Che Mohd Aziz Yaacob (2011). Isu dan Penyelesaian: Konflik Pemisah di Selatan Thailand. Malaysian Journal of History, Politics \& Strategic Studies. Vol 38(1), pp 13-34

2. Hans De Marie \& Isidore Collins (2011). Entrepreneurship Insecurity, Smuggling And Cross-Border Dynamics In Central Africa, Special issues on Africa, Universitaires Européennes

3. McClelland, D.C. (1961), Characteristics of Successful Entrepreneurs Journal of Creative Behavior, pp53-67, vol. 21, no. 3.

4. Casson, M. (1982). The Entrepreneur: An Economic Theory. Oxford: Martin Robertson.

5. Gurol, Y., \& Atsan, N., (2006). Entrepreneurial Characteristics amongst University Students: Some insights for Entrepreneurship Education and Training in Turkey. Journal of Education and Training, 48(1), 1-17.

6. Shane, S., Locke, E.A., \& Collins, C.J. (2003). Entrepreneurial Motivation, Human Resources Management Review, 13(5), 86-102.

7. Hansemark, O.C. (1998). The Effects of an Entrepreneurship Programme on Need for Achievement and Locus of Control of Reinforcement International Journal of Entrepreneurial Behavior \& Research, 4(1), 1-17.

8. Fauzi Hussin, Norehan Abdullah, Hussin Abdullah \& Selamah Maamor (2013). Aktiviti Ekonomi Sempadan di Perairan Sungai Golok - Rantau Pajang: Isu dan Cabaran. Persidangan Kebangsaan Ekonomi Malaysia ke VIII (PERKEM VIII), pp 235-245.

9. Habibah Ahmad, Hamzah Jusoh, Er Ah Choy, Amriah Buang, Sivapalan Selvadurai, Nurfarahin zainuddin, Mohd Kamarulnizam \& Sri Winarni Samsir (2014). Mengurus Pelancongan Sempadan Malaysia - Thailand: Kesepaduan atau Konflik. Malaysia Journal of Society and Space. Vol 10(8), pp 65-71.

10. Mohd Rosli Mohd Nor (2017)

11. Bruns, B., Miggelbrink, J., \& Muller, K (2011). Smuggling and Small-Scale Trade as Part of Informal Economic Practices. Penemuan Kajian Empirikal dari sempadan EU, Emarald Group Publishing Limited, pp 26-31

12. Merriman, D., Joossens, L., Frank J. Chaloupka., \& Yurekli, A (2000). Issues in the smuggling of tobacco products, pp 393-406.

13. Dutta, G (2010). Internationalization of Small Businesses of Border Region: A Study of the Determinants. Borderlands, Vol 25(3). 